\title{
Hogyan kutassuk járványunkat?
}

\author{
SIK ENDRE ${ }^{1}$
}

Mielőtt belevágnék, néhány adat a művek születésének kontextusáról: a NBER sok ezer műhelytanulmánya ${ }^{2}$ húsz program és tizenhárom munkacsoport terméke ${ }^{3}$. A Covid-kutatás március óta lendült bele: a Covid hívószóra (ha a címben fordult elő) már szeptember elejére több száz találat jelent meg, s a „social distance” fogalomra sem kevésbé igaz ez. ${ }^{4}$

1. Az első tanulmány ${ }^{5}$ azt vizsgálja, hogy az emberek miben hisznek (s mit nem hisznek el), illetve milyen korlátozásokat fogadnak el (s miket nem) a védekezés érdekében. A vizsgálat központi kérdése az, hogy az egyes társadalmi csoportok értékrendje milyen módon különbözik egymástól, s melyek azok a társadalmi jellemzők, amelyek növelik a járvány terjedését csökkentő védekező magatartás kialakulásának valószínűségét.

A kutatás két adatbázisra támaszkodott, az egyik egy 35 millió mobiltelefon térbeli mozgását érzékelő applikáció segítségével felépített adatbázis volt ${ }^{6}$. Ez az adatbázis lehetővé tette az otthon maradás, illetve a munkába járás hosszának és rendszerességének mérését ${ }^{7}$. A másik adatbázis az értékrend és a járvánnyal kapcsolatos viselkedés kutatására kidolgozott online vizsgálat volt. A kérdőív részben

\footnotetext{
${ }^{1}$ Debreceni Egyetem, Szociológia és Szociálpolitika Tanszék, sikendre0@gmail.com

${ }^{2}$ https://www.nber.org/papers.html

${ }^{3}$ https://www.nber.org/programs/

${ }^{4}$ Csökkenti ezt az értéket, hogy a vizsgált időszak elején a H1N1, az influenza és AIDS is tárgya volt a járványkutatásnak, ám növeli ezt az értéket, hogy olyan művek is érintik a Covid 19 járványt, ahol az nem szerepel a címben.

${ }^{5}$ Fan, Y. - Orhun, A. Y. - Turjeman, D. (2020): Heterogeneous Actions, Beliefs, Constraints and Risk Tolerance During the COVID-19 Pandemic (No. w27211). National Bureau of Economic Research. http:// www.nber.org/papers/w27211

${ }^{6}$ Melynek forrása a SafeGraph nevű adatbázis-építésre specializálódott vállalkozás (www.safegraph. com) volt. Az adatbázis anonimizálva tartalmazza az adott népszámlálási körzetben élők mobilhasználatának különféle jellemzőit, amit az elemzés során megyei szinten összesítettek az adatbázis építői, hogy az adatokat a járvány terjedésével, illetve a korábbi választási eredményekkel és népszámlálási adatokkal összevethessék.

${ }^{7}$ A teljes és a részidős munkavállalást a következő módon operacionalizálták: egy helyben, de nem otthon, lenni legalább hat (illetve 3-6) órán keresztül reggel nyolc és délután hat óra között. Ha a telefon egész nap otthon volt, akkor feltételezésük szerint a tulajdonos sem mozdult ki otthonról.
} 


\section{OLVASS FELESLEGESET!}

az egyén távolságtartásának (otthon maradt, kerülte a tömegközlekedést és a csoportos találkozási alkalmakat, otthonról dolgozott, nem találkozott a rokonsággal, a barátokkal), részben higiéniai gyakorlatára (gyakoribb kézmosás, vásárolt termékek megmosása, maszk viselése, kesztyű használata vásárlás során) kérdezett rá.

A tanulmány legfontosabb megállapításai nemcsak arra alkalmasak, hogy a védekezés irányítói finomra hangolják intézkedési terveiket, de a válsághelyzetben való viselkedés szociológiai elemzéséhez is jó kiindulópontot nyújtanak:

- ott, ahol magasabb a nők és a jobb módúak aránya, nagyobb mértékben csökkent az otthonról való eljárás aránya;

- a nők és a demokrata párt szimpatizánsai hajlottak inkább arra, hogy korlátozzák kapcsolataikat a külvilággal és többet törődjenek egészségük megóvásával;

- az alacsonyabb jövedelműekre a fentiek kevésbé voltak jellemzőek, s körükben - mivel jobbára olyan munkahelyeken dolgoztak, ahol távmunkára nem volt mód, illetve feltehetően a jövedelemkiesést is kevésbé viselték volna el az otthondolgozás és a tömegközlekedés elkerülése is ritkább volt;

- míg a nők inkább maguk és családjuk egészségéért, addig a szegények inkább az anyagi helyzet alakulása miatt aggódtak jobban;

- a nők a férfiaknál jobban aggódnak amiatt, hogy ha megfertőződnek, akkor súlyos lesz a betegség hatása;

- az alacsony jövedelműek optimistábbak a várható halálesetek számát illetően, és nem hisznek sem az állami intézkedések, sem saját védekezésük hatékonyságában.

2. Egy másik tanulmány ${ }^{8}$ szerzői abból indultak ki, hogy egyfelől az önkéntes távolságtartás, mint közjó az egész közösség számára értékes, s hogy ez kialakuljon, azt a közösség homogén volta elősegítheti. Másfelől, a távolságtartás elsősorban az egyén - legalábbis a járvány elején, amíg magát egészségesnek érzi, s tart attól, hogy megfertőződhet - számára hasznos elsősorban, s ilyenkor kevéssé motiválja az egyént, hogy másokat ne fertőzzön meg. Ha ez igaz, továbbá igaz az is, hogy akik megfertőződtek, azok kevéssé vannak tekintettel a más etnikumúakra, s ezért nem tartják be a távolságtartás szabályait, akkor egy etnikailag heterogén társadalomban az egészségesek fognak inkább otthon maradni (önvédelem), s ezért nem a homogén, hanem éppen a heterogén társadalmak lesznek távolságtartóbbak.

${ }^{8}$ Egorov, G. - Enikolopov, R. - Makarin, A. - Petrova, M. (2020): Divided we stay home: Social distancing and ethnic diversity (No. w27277). National Bureau of Economic Research. http://www.nber.org/papers/ w27277 


\section{OLVASS FELESLEGESET!}

A hipotézis tesztelésére az oroszországi mobilitáselemzéshez a Google Mobility Indexhez hasonló Yandex adatbázist (Yandex Isolation Index) használták ${ }^{9}$, amit kiegészítettek szövegbányászati és statisztikai adatfelvételek eredményeivel. Az USA esetében az előző tanulmányban már bemutatott SafeGraph adatbázist használták az elemzés során.

A kutatás eredményei azt mutatták, hogy Oroszországban a mobilitás már az első járvánnyal kapcsolatos ukáz (rendelet, amely március 29-én született meg) előtt csökkenni kezdett, s a heterogénabb etnikai összetételű (ahol az idegenellenesség mértéke is magasabb volt ${ }^{10}$ ) orosz városokban volt alacsonyabb az otthonról való eltávozás gyakoriságának aránya. AZ USA esetében is az etnikailag heterogénebb megyékben volt az otthon maradás értéke magasabb.

3. A járvány megfékezése/lelassítása érdekében hozott intézkedések egyik legkegyetlenebb eleme az otthon tartózkodás kényszere volt. Éppen ezért látták fontosnak a kutatók vizsgálni, hogy hatásos volt-e ez a kényszer a járvány csökkentésében $^{11}$.

Öt nagyvárosban (Atlanta, Boston, Chicago, New York (NYC) és Philadelphia) vizsgálták (ZIP-kód szintű körzetekre lebontva) a járvány terjedése és a mozgás (ön)korlátozása közötti kapcsolatot. A mozgás elemzése a már korábban bemutatott SafeGraph adatbázis segítségével történt, de most nem az otthon maradás vagy munkába járás dichotóm változójával dolgoztak, hanem az otthonról való elutazás változásának arányával, aminek viszonyítási alapja a járvány előtti (tavalyi) vagy a járvány kezdete kori (2020. február eleje) helyzet volt.

A nyers New York-i adatok azt mutatták, hogy ahol az egy évvel korábbi helyzethez képest nagymértékben csökkent az elutazások aránya, ott sokkal alacsonyabb volt a megbetegedések száma. Mivel ez az eredmény még nagyon sok tényező hatását is magában foglalta (például az egyes körzetek eltérő jövedelemszintje, a faj és kor szerinti összetétel), ezért bevontak olyan dimenziókat, amelyek ezen az aggregálási szinten mérhetők voltak, s feltételezték róluk, hogy kihathatnak a járvány terjedésének és a mozgás intenzitásának összefüggésére. Azt találták, hogy a mobilitás 10\%-os csökkenése az egy főre jutó megbetegedések 20\%-os csökkenésével járt együtt.

\footnotetext{
${ }^{9}$ A Yandex adatbázisnak (https://www.datacenterdynamics.com/en/analysis/cloud-russia/) a legtöbbet használt website Oroszországban (https://www.similarweb.com/top-websites/russian-federation).

${ }^{10}$ A Yandex Wordstat robotját használták az adott város médiájában előforduló idegenellenes találatok összeszámlálására.

${ }^{11}$ Glaeser, E. L. - Gorback C. - Redding, S. J. (2020): How much does COVID-19 Increase with Mobility? Evidence from New York and Four Other U.S. Cities NBER Working Paper No. 27519, http://www.nber. org/papers/w27519
} 